\title{
The Western Sahara conflict ${ }^{1}$
}

\author{
DR. MARTIN PABST \\ Politicai Analyst, Munich
}

The history of the Western Sahara has seen many developments familiar to Africa:

- the drawing of artificial boundaries in foreign European capitals at the turn of the century,

- clandestine agreements between colonial and regional powers without proper consultation with the territory's population,

- the sudden and irresponsible exit of the colonial power, Spain, which provoked the outbreak of hostilities between the contending parties (Morocco, Mauritania, the Liberation Movement Frente Polisario) at a time when the last Spanish officials and soldiers had not yet left the territory.

This conflict in a remote part of the Sahara desert has been long and painful. ${ }^{2}$ As early as 1957/58, West Saharan and Moroccan irregulars attacked the colonial troops in the territory which was then a Spanish colony. On 20 March 1973 the liberation moyement "Frente Populár para la Liberación de Seguía el-Hamra y Río de Oro" (Frente Polisario) started a guerrilla war - first against the Spanish administration, then against Morocco and Mauritania. The latter two countries had partitioned and annexed the territory following their clandestine "Madrid Pact" with the outgoing colonial power Spain (14th Nov. 1975). They claimed historic links between their countries and the people in the Western Sahara. The Advisory Opinion of the International Court of Justice confirmed certain links with Morocco and Mauritania, but did not support annexation: It stressed the right of self-determination of the inhabitants.

This paper was presented on 22 Sep 1998, during the International Peace and Security Conference hosted by the Faculty of Military Science, University of Stellenbosch (Military Academy), in commemoration of 50 years of United Nations peacekeeping, 1948-1998.

2 On the history of the Western Sahara conflict: Virginia Thompson and Richard Adloff, The Western Saharans (London, 1980). - Tony Hodges, Historical Dictionary of Western Sahara. (African Historical Dictionaries, No. 35, Metuchen, NJ, and London, 1982), xv-xxxix, 1-11. Tony Hodges, Western Sahara: The Roots of a Desert War (Westport, CT, 1983). - John Damis, Conflict in Northwest Africa: The Western Sahara Dispute (Stanford, CF, 1983). - Richard Lawless and Laila Monahan, eds., War and Refugees: The Western Sahara Conflict (London and New York, NY, 1987). - Yahia H. Zoubir, 'Origins and Development of the Conflict in the Western Sahara', in Yahia H. Zoubir and Daniel Volman, eds., International Dimensions of the Western Sahara Conflict (Westport, CT, and London, 1993), 1-16. - Anthony G. Pazzanita, Western Sahara (World Bibliographical Series, Vol. 190, Oxford and Santa Barbara, CA, and Denver, CO, 1996), xi-xxxvii. 
One day before Spain formally terminated its rule in the Western Sahara, Frente Polisario unilaterally declared a "Saharawi Arab Democratic Republic" (27 Feb. 1976). Since then, Algeria, the main rival of Morocco in the region, granted political and military support to Frente Polisario. Frente Polisario military attacks forced Mauritania to pull out of the war (1978) and to renounce her share of the former Western Sahara (1979), which was consequently annexed by Morocco, too. Frente Polisario military attacks against Morocco intensified afterwards, but diminished in the mid-80s, after the Moroccan army had completed a huge defensive wall with sophisticated electronic equipment. This sand-wall effectively protected nearly $90 \%$ of the territory from guerrilla attacks, although this measure did not completely end the war. In 1991 the UN brokered a cessation of hostilities, which has lasted up to now. A political solution is, however, still pending. In 1966 a UN General Assembly resolution had already demanded the implementation of the Saharawi's right to selfgovernment, but twice the colonial power Spain cancelled the promised referendum (in 1971 and 1975). After the Spanish withdrawal neither the OAU, the Arab League nor the UN were able to solve the problem.

Finally, in 1988 both Morocco and Frente Polisario accepted the UN Secretary General's settlement proposals. They provided for a interim period during which the special representative of the Secretary General would have sole and exclusive responsibility over all matters relating to a referendum, in which all the people of the Western Sahara would choose between independence and integration with Morocco. The United Nations Mission for the Referendum in Western Sahara (MINURSO) became operational in September 1991. It was established to monitor the cease-fire as well as to prepare and conduct a referendum, which was originally planned for 1992. However, the implementation process was soon lagging behind and in 1996 MINURSO was on the brink of collapse. In 1997 the newly appointed personal envoy of the UN Secretary General, James Baker III (USA), managed to broker an agreement on the main divergent views. Identification of voters resumed, but was repeatedly interrupted because of opposite views of the two parties. In January 2000 MINURSO published a provisional list of 86381 identified voters. However, more than 130000 (!) appeals have been forwarded, mainly from applicants living in Morocco. For the first time the UN Secretary General raised doubts that there could be consensual implementation of the settlement plan. He asked his Personal Envoy, James Baker III, to review the process and try to seek agreement between the parties.

Many factors have made a solution in the Western Sahara difficult. It is extremely difficult to identify legitimate voters in a territory composed of artificial boundaries and occupied partly by nomadic tribes. Furthermore, the conflict is embedded in a complicated framework of competing interests:

- political aspirations of the native inhabitants who share a long history of infighting and changing loyalties; 
- economic, strategic and political aspirations of rival regional powers (Morocco, Algeria, Mauritania); ${ }^{3}$

- economic, strategic and political interests of the former colonial powers in the Maghreb (France, Spain); ${ }^{4}$

- economic and strategic interests of the two super powers in the Cold War. ${ }^{5}$

The Western Sahara conflict, however, did not escalate into an open East-West confrontation, since the USA as well as the Soviet Union, enjoyed political and economic relations with both Morocco and Algeria at the same time. The super powers have only taken limited interest in the conflict, which does not promise many gains for them, and which seems to be rather complicated from the outside and is situated in a fragile region.

Furthermore, the conflict did not escalate into a regional war, since Algeria, apart from the beginning of the military conflict, refrained from taking part in military actions. ${ }^{6}$ This contributed to the containment of the Western Sahara conflict during the Cold War, but also prolonged it afterwards. The Western Sahara case clearly shows that lack of outside intervention can contribute to the perpetuation of a conflict.

Initially many observers believed that Frente Polisario's resistance would gradually wear down. It never managed to win strong allies: Its "Saharawi Republic" has mostly been recognised by Third World countries. After the finalisation of Morocco's defensive wall Frente Polisario could not hope for a military victory any longer.

Morocco could make full use of the resources of an independent state and enjoyed considerable support from powerful allies: Already in 1975 US Secretary of State, Henry Kissinger, had backed Morocco's and Mauritania's partition plan and sold it to the hesitating

3 Cf. Robert A. Mortimer, 'The Greater Maghreb and the Western Sahara', in Yahia H. Zoubir and Daniel Volman, eds. (see note 1), 169-185. - Anthony G. Pazzanita, 'Morocco versus Polisario: a Political Interpretation', The Journal of Modern African Studies, 32/2 (1994), 265-278.

4 Cf. Phillip C. Naylor, 'Spain, France and the Western Sahara: A Historical Narrative and Study of National Transformation', in Yahia H. Zoubir and Daniel Volman, eds. (see note 1), 17-51.

5 Cf. Leo Kamil, Fueling the Fire: U.S. Policy and the Western Sahara Conflict (Trenton, 1987). Stephen Zunes, 'The United States in the Saharan War. A Case of Low-Intensity Intervention', in Yahia H. Zoubir and Daniel Volman, eds. (see note 1), 53-92. - Richard B. Parker, 'U.S. Strategic Interests and the War in the Western Sahara', in Yahia H. Zoubir and Daniel Volman, eds. (see note 1), 93-102. - Yahia H. Zoubir, 'Moscow, the Maghreb, and Conflict in the Western Sahara', in Yahia H. Zoubir and Daniel Volman, eds. (see note 1), 103-125. - Karin von Hippel, 'The NonInterventionary Norm Prevails: an Analysis of the Western Sahara', Journal of Modern African Studies, 33/1 (1995), 67-81. - Yahia H. Zoubir and Daniel Volman, 'The United States and Conflict in the Maghreb', The Journal of North African Studies, $2 / 3$ (1997), 10-24. - Stephen Zunes, 'The United States and the Western Sahara Peace Process', Middle East Policy, V/4 (1998), 131-146. - Stephen Zunes, 'New Hope for Western Sahara', Peace Review, 10/2 (1998), 241-247.

6 Only in January 1976 did Algerian soldiers actively take part in combat. They supported Polisario fighters against Moroccan units in the battle at Amgala. The Moroccans captured about one hundred Algerian soldiers. David Seddon. 'Morocco at war', in Richard Lawless and Laila Monahan, eds. (see note 1), 100. 
Spaniards, because he did not want "another Angola on the Eastern flank of the Atlantic Ocean"7. Spanish decolonisation reminded him too much of the Portuguese precedent one year earlier. The United States together with France have repeatedly softened Security Council Resolutions against Morocco and prevented enforcement mechanisms. Morocco boasted of vital diplomatic and military support from France and the USA, whereas Frente Polisario only received cautious Soviet backing in the international arena and a limited number of Soviet weapons via Algeria. The United States have not been uncritical towards Morocco, but tended to support the conservative Kingdom which they regarded an important ally and logistical base for American foreign policy in Africa and the Near East. In the past it served as bulwark against communism, now against Islamism.

The conflict, however, did not disappear from the scene. Frente Polisario's wellmotivated guerilleros - numbering some 10 to 15000 - have maintained a striking capability and make the Moroccan administration of the territory very costly. Approximately 150000 Moroccan soldiers are permanently stationed in the Western Sahara, approximately one half of the army. Furthermore, Frente Polisario managed to keep the Western Sahara question on the international agenda, even after the Soviet Union had collapsed and its main supporter, Algeria had to face internal turmoil.

The military and political stalemate forced both sides to accept the UN peace plan. It soon turned out that the two parties had divergent views regarding the criteria for voter eligibility. ${ }^{8}$ Frente Polisario insisted that only the 73497 inhabitants, which were counted by the Spanish administration in 1974 , and their descendants form the basis for a referendum. Frente Polisario hopes for a quick implementation of a referendum, since far more than 100000 West Saharan exiles (having lived in tents in Western-Algeria for nearly 25 years) desperately want to return home. However, time is not on Frente Polisario's side. Frente Polisario repeatedly accused Morocco of delaying the process, of blackmailing MINURSO and loading the voters' list with foreigners.

Morocco argued with some justification, that the Spanish census had to be modified as a number of Western Saharans had fled from Spanish colonial rule to Morocco and nomadic tribes had not properly been represented in the Spanish census. It seemed, however, that Morocco did not speed up the implementation of the process. Originally it had demanded that no less than 170000 additional names should be added to the list, and MINURSO members repeatedly criticised Morocco to be uncooperative in many ways. ${ }^{9}$

In the mid-90s the MINURSO operation became more and more ineffective. The US Congress regarded it as a symbol of UN waste and inefficiency by the US Congress. MINURSO seemed to repeat the UNPROFOR example in Bosnia-Herzegovina: an undermanned and under-equipped mission deployed between contesting parties without a

7 Quoted from Leo Kamil (see note 4), 10.

8 Stephen Zunes, 'Western Sahara: Peace Derailed', Current History (May 1996), 230-233. - Jarat Chopra, 'Quitting Western Sahara', Geopolitics and International Boundaries, 1/1 (1996), 62-70.

In February 1992 US Assistant Secretary of State for International Organization Affairs John R. Bolton acknowledged that Morocco had been "unhelpful". Quoted from Stephen Zunes, "New Hope for Western Sahara' (see note 4), 243. 
clear political strategy for implementing and enforcing a timetable. About 500 civilian, police and military personnel (which are to be increased to 2800 in the interim period) monitor approximately 170000 troops on both sides. Soon the mission developed into an instrument to perpetuate the status quo in the territory and separated rather than brought the two parties together. As in Bosnia-Herzegovina, there were also allegations of MINURSO bias in favour of the dominating party. ${ }^{10}$

In 1997 the United States waged a concerted effort to bring about a solution in the Western Sahara. They changed to an active and more neutral role in the West Sahara conflict and lent one of their most capable negotiating teams to the new UN General Secretary Kofi Annan namely James Baker III, former US Secretary of State, as personal envoy of the UN Secretary General, aided by Chester Crocker (former US Assistant Secretary of State for African Affairs), and John Bolton (former US Assistant Secretary of State for International Organisations).

James Baker managed to bring about direct talks between the two parties and brokered the "Houston Agreement", which includes the following points: "

- Only a limited number of sub-tribal groups will be added to the Spanish census and assessed during the voters' identification process;

- members of the three contested sub-tribal groups will only report individually to the Identification Commission and not be sponsored by Morocco on a large scale;

- the United Nations High Commissioner for Refugees (UNHCR) will be in charge of the repatriation of refugees;

- the UN will have the sole and exclusive authority on all matters relating to the referendum;

- the parties agree on a code of conduct for the interim period, which includes freedom of expression and freedom of movement for all inhabitants as well as for international observers;

10 Frank Ruddy, former deputy chairman of MINURSO (Feb.-Dec. 1994), accused UN Secretary General Boutros Boutros-Ghali and his Special Representative Erik Jensen to have acceded to complete Moroccan control of the identification process. Ruddy made a sworn testimony before the US Congress on 25 January 1995, but was barred by the UN Secretary General from stating his case to the Fourth Committee of the United Nations. (Statement of Ambassador Frank Ruddy, United States House of Representatives, Review of United Nations Operations and Peacekeeping, Committee on Appropriations, Subcommittee on the Departments of Commerce, Justice, State, and the Judiciary and Related Agencies, Washington, DC, United States Government Printing Office, 25 January 1995) - Cf. also WESTERN SAHARA: THE REFERENDUM THAT WASN'T AND THE ONE THAT STILL MIGHT BE. Address by The Honourable Frank Ruddy Former United States Ambassador. The Middle East Institute, June 19, 1998. - Similar criticism was leveled by Douglas K. Dryden (Address to the United Nations Fourth Committee by Douglas K. Dryden, former US Military Representative to the Special Liaison Office of MINURSO, Western Sahara, United Nations, 7 October 1996) and by other US officials of MINURSO.

1 United Nations, Security Council. S/1997/742, Report of the Secretary General on the Situation Concerning Western Sahara, 24 September 1997. 
- nothing is agreed before everything is agreed upon.

Why did the US take up a leading role in the Western Sahara conflict for the first time? ${ }^{12}$ It seems that Washington has come to the conclusion that neither side has the potential to win the war militarily. In 1994 Frente Polisario had threatened to resume hostilities, should the implementation process get stuck. Such escalation could now destabilise the whole region, since there is a murderous civil war taking place in Algeria. Washington has moved politically much closer towards the Algerian government, whereas Morocco today is not as important an ally today as it was during the Cold War. In addition, the United States are exploring promising mineral resources in Algeria. Growing tensions between Algeria and Morocco might furthermore lead to vice-versa encouragement of Islamist opposition groups. A desperate Frente Polisario could take to international terrorism, as it once threatened to do in $1996^{13}$, and intensify links with dissident movements in the neighbouring countries, not only in Algeria, but also in Mali and Niger. Saharawi refugees could lose their hope for a peaceful solution and move from Algeria to neighbouring countries in the South, thereby destabilising these countries and their fragile ethnic and political balance.

The United States does not perceive a Frente Polisario government as a security threat for the United States any longer, as it is neither Islamist nor socialist (and has probably never been hard-core Marxist-Leninist). There is also no danger of Soviet, Cuban or Libyan involvement in the conflict any more.

It must also be taken into account that ongoing conflict in the Western Sahara will jeopardise the future of the fragile Arab Maghreb Union and thereby indirectly destabilise the region, too. Furthermore, it seems that the United States seem to be interested in expanding their influence in North Africa at the expense of France, as is the case in Central Africa. Therefore the United States pressurised both parties, and especially the Moroccan King Hassan, to come to an agreement on the disputed questions.

In September 1998 the identification process was completed (with 147350 applicants convoked), with the exception of the members of three sub-tribal groupings. Furthermore, status-of-forces and status-of-UNHCR agreements with Morocco were still pending. In October 1998 the UN Secretary General, Kofi Annan, presented a package to the parties in order to speed up the implementation. This included:

- the initiation of the appeals process for already identified applicants at the same time as the identification of remaining applicants from the three sub-tribal groupings;

- the effective formalisation of the presence of the Office of the UNHCR in the territory to allow the necessary preparation for the repatriation of refugees;

12 Yahia H. Zoubir and Daniel Volman, 'The Unites States and Conflict in the Maghreb' (see note 4), 18-22. - Stephen Zunes, 'The United States and the Western Sahara Peace Process' (see note 4), 141-144.

13 Internationales Afrikaforum, $32 / 2$ (Bonn, 1996), 129. 
- a revised schedule, under which the transitional period would start in June/July 1999 and the referendum be held in December 1999.

Whereas Frente Polisario acceded to the package in November, the Moroccan government demanded certain amendments. Again the referendum process was halted. On 31 January 1999 the UN Security Council increased its pressure on Morocco and threatened not to extend MINURSO's mandate. In a more constructive mood, Morocco then entered into discussions about the implementation of identification and appeals protocols; it also signed status-of-UNHCR and a status-of-forces agreements in January and February 1999 respectively. ${ }^{14}$

In April 1999 UN Secretary General, Kofi Annan, presented a new timetable: ${ }^{15}$

1 June 1999 - November 1999

15 July 1999 - February 2000

February 2000

July 2000
The identification of additional voters (most of them will apply from Morocco),

The appeals process,

The start of the transitional period,

The conducting of the referendum.

In order to give the process new momentum, UN Secretary General, Kofi Annan, appointed William Eagleton, former US Ambassador to Syria, as his new Special Representative in May 1999. On $15^{\text {th }}$ July 1999 a provisional voters' list comprising 84251 names was published. Additional voters' identification and the appeals process have started successfully. But the optimism was premature. When on 17th January 2000 MINURSO published the second part of the provisional voters' list, Morocco strongly questioned the outcome. Of the 51220 applicants from the three contested sub-tribal groups, only 2130 individuals had been recognised as having the right to vote. Added to the first list of 84251 voters, the total number of voters stands at 86381 out of close to 200000 auditioned applicants.

The Moroccan government expressed its "shock and disappointment" questioned the identification procedures. In particular, it charged that oral testimony was not properly processed. The Moroccan government stated that it could not accept a referendum "that does not include the participation of all of the citizens from the southern provinces". ${ }^{16}$

With close to 140000 appeals submitted, the prospect of a referendum seems more remote than ever. The Front Polisario questions the justification of most appeals on formal

14 United Nations, Security Council, S/1999/307, Report of the Secretary General on the Situation Concerning Western Sahara, 22 March 1999.

15 United Nations, Security Council, S/1999/483, Report of the Secretary General on the Situation Concerning Western Sahara, 27 April 1999. 
grounds and warns not to delay the timetable any further. Frente Polisario representatives repeatedly threatened to take to arms again, should the settlement plan prove unworkable.

In his pessimistic Report dating from 17 February 2000 the UN Secretary General had to admit that the timetable envisaged was no longer valid. ${ }^{17} \mathrm{~A}$ date for the referendum, which had been repeatedly postponed since 1992 , could not be set with certainty. He also referred to the fact that there was no progress made with respect to cross-border confidence-building measures, as mentioned in the Security Council Resolution 1282 (1999). Furthermore, the UNHCR draft repatriation protocol had not been concluded with the four parties Algeria, Frente Polisario, Mauretania, Morocco because of some fundamental differences between the parties.

For the first time the Secretary General questioned the practicability of a referendum. He asked his Personal Envoy, James A. Baker III, to consult again with the parties in order to explore ways and means to achieve an early, durable and agreed resolution of their dispute. In its resolution 1292 (2000) UN Security Council supported the efforts of James Baker and extended the mandate of MINURSO until 31 st May 2000. Baker invited the four key players Morocco, Frente Polisario as well as Algeria and Mauritania - to a conference in London in May.

Africa could experience "another Angola" in the Western Sahara - in a sense different of what Henry Kissinger had in mind in 1975: The losing party could take to arms again, should it not be willing to accept the result of the referendum or the way it was conducted. There is no enforcement mechanism envisioned by the settlement plan calling for the use of military means in case the result were not to be recognised and accepted by one party. This danger must be taken into account, since the two parties have settled for a "winner takes all" instead of a compromise solution, which could mean autonomy for the Western Sahara within the Moroccan Kingdom.

The following main conditions seem to be necessary for a successful referendum:

- continuing leadership and pressure from outside,

- a strict timetable and clear commitments from both parties,

- consequences from the side of MINURSO when engagements are not met,

- quick repatriation of refugees, which will make the implementation of the settlement much more probable,

- some follow-up mechanism which is not part of MINURSO's mandate (it only provides the retreat of MINURSO personnel within four to six weeks after the referendum),

- back-stage agreements between Morocco and Frente Polisario to accommodate the loser (as was essential in the South African negotiated transfer of power). 
One can only speculate if such a back-stage deal was struck in Houston or will still be on the agenda. ${ }^{16}$ In case of a Frente Polisario victory, it could mean a Frente Polisario guarantee to respect Moroccan citizens and economic interests in the territory, as well as a sort of confederation between a Saharawi Republic and Morocco. In case of a Moroccan victory, it could mean a certain degree of autonomy for the province of Western Sahara and a degree of power sharing for a certain period. In both cases there should be agreement on an amnesty mechanism and on ways of coexistence between remaining Moroccan settlers and returning Saharawi refugees.

In May 1999 the Moroccan King Hassan II died and was succeeded by his son Mohammed. The new king sacked the Minister of the Interior Driss Basri, a long-time hardliner, and announced a more conciliatory policy towards the Western Sahara. Though Mohammed VI has not questioned Morocco's sovereignty in the territory, he hinted at the possibility of a solution leading to the territory's autonomy. ${ }^{19}$ Although both parties officially stick to the original settlement plan, there may now be more flexibility in the coming negotiations.

Africa's last decolonisation conflict has reached a threshold. If James Baker manages to broker a "Houston II agreement", we could probably see a lasting settlement - with or without a referendum. If not, a protracted desert war would start again.

16 Africa Confidential mentions insiders suggesting "US-backed assurances for both sides" ('Desert Diplomacy', Africa Confidential 39/2 [23 January 1998], 5) - Recently New York Times journalist John Burns speculated that James Baker had brokered a secret deal between Polisario and Morocco, guaranteeing Moroccan sovereignty for 25-30 years in exchange for Saharawi autonomy (New York Times, 16. June 1999). 